\title{
ANALYSIS OF THE PERSPECTIVES OF INTERNATIONAL ENVIRONMENTAL COOPERATION FOR THE CENTRAL REGIONS OF UKRAINE
}

\author{
Lesia Petkova \\ Department of International Economics and Business \\ Cherkasy State Technological University \\ 460 Shevchenko blvd., Cherkassy, Ukraine, 18006 \\ l_petkova@ukr.net \\ Elena Khomenko \\ Department of ecology \\ Cherkasy State Technological University \\ 460 Shevchenko blvd., Cherkassy, Ukraine, 18006 \\ homenko@uch.net \\ Nelli Zagoruyko \\ Department of ecology \\ Cherkasy State Technological University \\ 460 Shevchenko blvd., Cherkassy, Ukraine, 18006 \\ nelli.zagorujko@ukr.net
}

\begin{abstract}
The conducted analysis of the prospects of international environmental cooperation for the central regions of Ukraine showed that the most developed area of cooperation is green tourism, which is rapidly developing in the central regions. To a large extent, this is due to the natural conditions and the preserved archaism of local life that attracts tourists. On the other side, the support of green tourism by the government, improvement of the material condition of owners of green homesteads increases the interest of local communities in cooperation with international organizations.

Using of international experience in the field of energy saving by local communities is being implemented by individual farms at the level of individual relationships with international organizations, but it has no massive component.

Cooperation of the central regions of Ukraine with the international community is the most promising in the direction of forming a transnational ecological network. The main reserve for the formation of a regional ecological network is the lands of the water fund, degraded and unproductive agricultural landscapes. The allocation of lands for the water fund and its mapping must use plans and requires adequate financing. The threat to implementation of the regional program for the development of the ecological network and its coordination with transnational ecological corridors is the lack of financing and inconsistency of the resolution of the land ownership rights in the alienation of land to the nature reserve fund.

The use of funding from international environmental funds in the central regions of Ukraine is limited due to the lack of experience in the participation of environmental NGOs in international ecological projects aimed at nature conservation, the lack of interest of local communities in land alienation in the nature reserve fund.
\end{abstract}

Keywords: transnational cooperation, ecological network, green tourism, sustainable development.

\section{Introduction}

The new dimension of aims of the sustainable development and modern geopolitical preconditions determine the Ukraine's need in the global partnership development that provides formation of sustainable long-term inter-regional links and effective transnational cooperation. Successful realization of tasks of the sustainable development in the society is impossible without setting comprehensive partner relations between governments, business-structures and civic society at global, regional and local levels, directed on solving socio-economic and ecological tasks.

The dynamics of the euroregional cooperation development testifies to its essential intensification, connected, first of all, with realization of the general European aim - washing out borders 
between countries-members of the European Union (EU) and leveling disproportions of development of peripheral and central regions in each state [1].

Ukraine signed the Association agreement with the European Union already in 2014 that became a beginning of the way to full value membership. Among questions, faced by the Ukrainian state in this direction is a problem of integration and cooperation with international ecological programs that provide the population's sustainable development. The experience of EU countries indicates efficiency of the development of new forms of transborder cooperation in different branches of economy, including in solving socio-ecological problems. In first turn it concerns adjacent countries. The geopolitical position of Ukraine, which 19 regions among 25 are border ones and which external border is the longest among European countries, conditions great potential possibilities of the development of border and transborder cooperation. For example, in 2013 there was created the Scientific information-statistical transborder cluster "Infostat" with participation of the Ukrainian and Polish sides for realizing the potential of transborder cooperation [2]. Along with it, possibilities and potential of local Ukrainian communities of the central regions of Ukraine in the transborder cooperation development are insufficiently studied.

The new conception of "involvement” by the principle „,cooperation-without-frontiers” provides the common purposeful mutually agreed activity (of power, population, business of neighbor countries) for solving social, economic, ecological and other problems of territorial communities of neighbor countries. At such cooperation the field of interconnection is widened and covers not only adjacent territories, but also more remote ones, which have common problems and possibilities of their common solution. In the modern global world ecological troubles become a problem of the whole civilization and need close cooperation between all countries for their solution. Partnership must cover the maximal number of spheres, which coordinated actions provide appearance and intensification of the synergetic effect of cooperation that will favor solving the global ecological crisis.

The global character of modern ecological problems allows to study possibilities of the coordinated work of different countries-members in transnational cooperation and makes the task of fuller involvement of Ukraine in the international community more urgent.

\section{Analysis of literary data and statement of the problem}

International ecological cooperation in the world develops fast because of urgency of solving problems of global warming, climate change on the planet and threatening rates of extinction of the modern flora and fauna [3]. International ecological cooperation of Ukraine is realized within international law. Along with it, despite powerful legal ecological instruments, the external natural environmental state of the country worsens very fast, the threat of man-caused catastrophes that threaten also neighbor countries, grows. The question of Ukrainian transborder cooperation in the context of actual processes of European integration and decentralization were considered at the level of parliamentary hearing that determined that transborder cooperation in different forms of inter-territorial cooperation is not only an effective factor of international activity of Ukraine, but also an important instrument of the development of regions, cities and territorial communities, first of all, ones that border with neighbor countries or have sustainable relations with territorial partners in other countries [4].

Topicality. Problems of transborder pollution of natural resources and non-rational nature management are the ones of most urgent and acute problems of modernity and need participation of all states at both national and transnational levels, especially, states-neighbors. Scientists just state that ecological problems are not limited by national borders, they has the general planet character. The problem of environment protection and rational nature management gained special urgency in the last years because of deepening the ecological crisis, overproduction and extensive usage of natural resources.

The ecological policy of Ukraine and Poland has common development directions, but also differences in internal instruments and results $[5,6]$. The main defect of Ukraine in the ecological policy is the absence of the effective economic-legal mechanism of environment protection. There takes place implementation of the European legislation by the simple translation of EU norms without taking into account ecological, political, economic and other realities of Ukraine. 
The most effective forms of transborder cooperation in their influence on the developments of regions are transborder projects and Agreements as to transborder cooperation. Transborder innovative structures, transborder clusters and euroregions don't play an important role in the development of border regions [7]. The example of successful international cooperation in solving ecological problems is realization of common transborder projects. Today Europe includes more than 180 euroregions, where Ukraine is also involved. Among them: Lviv region (Carpathian euroregion) and Volyn region (euroregion "BUH"). The main aim of euroregions' creation is harmonization of the development of border territories, which indicators are the number of projects of the cultural, ecological direction for solving common problems of territorial communities of transborder regions.

The essential experience in realization of international ecological problems by several countries belongs to the Carpathian convention. Since 2006 Czechia, Hungry, Slovakia have worked for saving Carpathians together with Ukraine. The main aim of the Convention is the comprehensive policy and cooperation of sides for protection and sustainable development of Carpathians for improving the life quality, strengthening local economies and communities, saving natural values and cultural heritage. Introduction of arrangements of the Carpathian convention in Ukraine is reala ized with involving regional state administrations in Transcarpathian, Ivano-Frankivsk, Lviv and Chenivtsi regions, Ministry of international affairs of Ukraine, Ministry of finances of Ukraine, Ministry of economic development and trade of Ukraine, Ministry of agrarian policy and food of Ukraine, Ministry of health protection of Ukraine, Ministry of culture of Ukraine, State agency of forest resources of Ukraine, State agency of land resources of Ukraine, State agency of water resources of Ukraine, Ministry of infrastructure of Ukraine, National academy of science of Ukraine and National academy of agrarian science [8]. Direct execution of tasks of the Carpathian convention is subordinated to state administrations of ecology and natural resources in regions, directorates of national parks and scientific institutions. Financing of nature protection programs within the Convention is realized by tender procedures from the State fund of protection of the external nature environment of Ukraine and from international economic organizations by grants.

A source for financing ecological projects for improving the state of the natural environment may be the LIFE-program that is a single financial source of the European Union, devoted exceptionally to co-financing of projects in the branch of the national environment and climate. The main aim of the program is revelation and promotion of new solutions of ecological problems. In February of 2017 the Verhovna Rada ratified the agreement between the Cabinet of ministries and government of Germany about financial cooperation. Thus, Ukraine can receive a grant soon in amount of $14 \mathrm{mln}$ euro for realization of the project "Support of natural-protected territories of Ukraine". This project is directed on building infrastructure objects at nature protected territories, development of the managerial system, based on local communities' participation, preservation of biodiversity, based on the sustainable development of regions. It is planned to apply the stage approach for these aims. At the beginning it includes two nature protected territories in Carpathians (nature reserve "Gorgany" and Carpathian biosphere reserve) [9].

International ecological cooperation has the long experience in Western regions of Ukraine that is connected with peculiarities of their geographic location and border with EU countries. Such cooperation is limited in the Central Ukraine, the analysis of possibilities of effective ecologic cooperation of the central regions of Ukraine with other countries for solving global problems of the natural external environment are not studied. Today there are international programs, directed on energy efficiency and introduction of alternative energy sources in life of Ukrainians. The association "Energy effective cities of Ukraine" created an on-line catalogue that gives an access to donor and investment resources in the sphere of energy saving and energy efficiency and protection of the external natural environment, presented in Ukraine. These programs have, first of all, the socio-economic importance for the development of local communities, but not directed on saving the biodiversity of ecosystems.

The strategy of the national ecological policy of Ukraine for the period till 2020 sets several aims, among which the special place belongs to stopping losses of the biological and landscape diversity and forming an ecological network. Formation of an ecological network provides changes 
in the structure of the land fund by attributing (based on substantiation of ecological safety and economic expedience) a part of agricultural lands to categories, subjected to the special protection with renewing their specific diversity of natural landscapes. It is an example of the general state mechanism of achieving the harmonic co-existence between society and nature in its territorial and biotic diversity. Creation of the national eco-network provides expanding borders of natural reserves, biosphere reserves and national natural parks, increasing the general area of the natural-reserve fund of Ukraine, introducing the system of nature protective arrangements for saving bio- and landscape diversities and expanding the area of the natural-reserve fund up to 15 percent of the total territory of the country in 2020 [10].

Formation of the transnational eco-network with transborder ecological corridors may become a component of the common international ecological activity in the context of the sustainable development of Ukraine. The idea to create ecological corridors for connecting places with the preserved biotic diversity and objects of the cultural-natural heritage - ecological kernels is not new $[11,12]$. These corridors allow to save the biotic diversity and objects of the cultural-natural heritage with the historical, ethnic and spiritual potential for a long perspective. The questions, connected with projection and realization of the eco-network idea, need making inter-state (national) decisions and must be realized within the general European cooperation. The program, named «Nature-2000» functions in Europe for organization of Special Areas of Conservation [13]. The European eco-network is a net of natural protected territories, directed on the support of the biological diversity by saving separate determined biotypes (near 250) and separate varieties of the wild flora (near 430) and fauna (200) at the European territory. The eco-network program «Nae ture-2000, realized by countries of the European Union, plays a key role in protection of the ecological diversity of the EU territory by saving certain types of natural areals of species of animals and plants, threatened by disappearance. It is not limited by key zones that have an exceptional importance for saving the biodiversity, but includes also buffer zones and ecological corridors, necessary for saving migrating species. The program «Nature-2000» allows to use territories and natural resources under condition of providing the general aim - saving defined zones. But these territories are formed also by countries, not members of EU, according to the statements of the Convention about protection of the wild flora and fauna and natural living environments in Europe (Bern convention 1979) [14]. This Convention is aimed at protecting the wild flora and fauna and their natural areals. The special attention is paid to species, threatened by disappearance, and vulnerable species, including migrating ones. The convention of 1979 together with Recommendation No. 161989 and Resolution No. 31996 to it made the ground for creating the Emerald Network that is an analogue of the program «Nature-2000» and functions beyond EU, developing the common European approach as to protection of natural areals. Objects within the Emerald network together with territories within the program «Nature-2000» form the kernel of the Pan European Ecological Network (PEEN) [15].

\section{Aim and tasks of research}

The realized studies were aimed at analyzing possibilities of transnational cooperation in the central region of Ukraine for solving socio-ecological tasks of the sustainable social development.

The following tasks were solved for attaining the set aim:

- To analyze prospects and threats of realization of the regional scheme of the eco-network in Cherkasy region as one of the central regions of Ukraine;

- To estimate perspectives of introducing the program of energy efficiency and energy saving of Cherkasy region with involvement of international cooperation;

- To determine perspectives of the development of green tourism in the content of the sust tainable regional development.

\section{Materials and methods of research}

The initial fact material was obtained by the analysis of literary sources. There were used also the own complex studies of the state of natural water bodies of Cherkasy region, involved in realization of the regional development program of small hydroenergetics, conducted in 2016-2017. 
At the processing and analysis of initial materials, there were used scientific methods of systematization: field, statistical, comparative-descriptive, landscape, analytic.

\section{Research results}

5. 1. The analysis of prospects and threats of realization of the regional scheme of the eco-network in Cherkasy region as one of the central regions of Ukraine

The conception of an eco-network has been actively introduced in Ukraine already since 2012, when the Statement of the Verhovna Rada of Ukraine of 13 of May of 2011 No. 3358-VI inset the State program of formation of the national ecological network for 2000-2015 in the list of state target programs, planned to be financed within priority directions. Scientists offered three territorial levels of eco-networks, especially, national (inter-regional), regional and local. Cartographic models of regional eco-networks were developed for almost all administrative regions of Ukraine, and programs of their formation were accepted by decisions of regional administrations [16].

According to the assessment of the American scientist Y. Odum [17], the ratio between natural and anthropogenic landscapes must be from $60 \%$ to $40 \%$. Landscapes of Cherkasy region are characterized with the essential transformation: $75,09 \%$ of the area of the region are agricultural and economically used territories. This region within the Middle Dnipro surroundings, the most ameliorated region of the Forest and steppe zone of Ukraine (the degree of lands' melioration reaches $60,79 \%$ ), with least number with reserve objects (3,0\% of territories) has extremely urgent problems of saving the landscape and biotic diversity, increasing ecosystems' bioproduction, development of ecotourism and health protection. Cherkasy region has high indices of the landscape and biotic diversities, enough resources for increasing the area of the natural-reserve fund up to $8 \%$ of the area of the region. Along with it the Program of the development of the regional eco-network of Cherkasy region for 2013-2020 functions there. The total area of the Cherkasy regional eco-network is 759,2 thousand ha. Key territories of the eco-network include territories and objects of the natural-reserve fund $(63,1$ thousand ha), water-marshy lands $(166,28$ thousand ha) and other territories with saved valuable natural complexes. The part of natural-reserve territories in the region is for today 3,0\%, in Ukraine, the reserve index is 6,1\%, at that in most European countries areas, occupied by nature-reserve territories are in average $15 \%$. The state strategy of the regional development of Cherkasy for the period till 2020 (Table 1) provides the increase of the specific weight of the area of the natural-reserve fund for the area of an administrative-territorial unit for Cherkasy in 2017 up to $6,6 \%$, in $2021-$ up to $9 \%$ [18].

The main reserve of formation of the regional ecological network of Cherkasy region is lands of the water fund, degraded and low-productive agro-landscapes. Separation of lands of the water fund in nature and their mapping on land management plans need correspondent financing and projecting. A threat of the regional policy realization for developing the ecological network is the insufficient financing and non-coordination of the ownership right resolution at alienation of lands in the natural-reserve fund.

The example of local communities' distrust and non-acceptance of programs for expanding the natural reserve fund is efforts to create the Kholodny Yar national natural park on the base of the territory of Kholodny Yar that is at the same time a historical and natural raisin of Cherkasy region. Despite all attempts of ecologists and historians, alienation of 3,5 thousand ha of forest is inadmissible for Kamiansky forest economy and this question is not solved at the level of the Verkhovna Rada of Ukraine.

Another bad example is the history of attempts to create the national natural park "Cherkasky pine forest". The Cherkasky pine forest has the area 28,5 thousand ha, and together with Irdyn bog and Moshnohyrsky ridge is 41,7 thousand ha. The Cherkasky pine forest includes 23 objects of the natural-reserve fund on the total area 2 thousand 169 ha, among which are reserves: Dahnivsky, Rusko-Plyansky near bogs; 14 natural monuments and 3 parks-monuments of the garden-park art. Its ecological state essentially worsened in the last decades, despite the fact that some part of it is protected. Conducted studies of local scientists [19] demonstrated that forest plants in the radius $20-30 \mathrm{~km}$ from the industrial zone of the city suffered from the negative aerogenic influence. Sanitary arrangements, realized in forests, result in simplification of tree stands 
structure. It is favored also by the change of soil-hydrological conditions, frequent forest fires, recreational load. The Cherkasky pine forest suffers from cutting in 12,3 thousand $\mathrm{m}^{3}$ annually that results in decreasing native tree stands. Its part was given for a military polygon, another one - for a city dump. Creation of the National natural park "Cherkasy pine forest" was planned by the Statement of the Verhovna Rada of Ukraine "About the program of the perspective development of the reserve affair in Ukraine" already in the first years of Ukrainian independence [20], the Law of Ukraine "About the state program of formation of the eco-network in Ukraine for 2000-2015" [21]. The area, offered for inclusion in the national park, can be separated in two clusters:

- Cherkasky pine forest -8 thousand ha;

- Irdyn bog - 5,5 thousand ha;

- Moshohyrsky ridge $-2,75$ thousand ha.

Unfortunately, today the question about creation of the Cherkasy national natural park is not considered even in the elaborated strategy of the development of Cherkasky region till 2020.

Table 1

Spheres of realization of ecological projects in the State strategy of the regional development of Cherkasy region for the period till 2020

\begin{tabular}{|c|c|}
\hline Tasks & Possible spheres of realization of projects and programs \\
\hline $\begin{array}{l}\text { 1. Preservation of objects of the natural- } \\
\text { reserve fund, rare and disappearing species } \\
\text { of flora and fauna }\end{array}$ & $\begin{array}{l}\text { - Creation of new objects of the natural-reserve fund } \\
\text { - Establishment of limits in nature of existent objects of the natural-reserve fund } \\
\text { - Use of the recreational potential of territories and objects of the natural-reserve } \\
\text { fund } \\
\text { - Formation of lists of rare and disappearing species of flora and fauna } \\
\text { - Arrangements as to protection and restoration of water bioresources }\end{array}$ \\
\hline $\begin{array}{l}\text { 2. Preservation of forests and green plants } \\
\text { in settlements of the region }\end{array}$ & $\begin{array}{l}\text { - To realize inventorying of green plants in cities and districts of the region } \\
\text { - Increase of the area of green plants in settlements of the region, creation of forests } \\
\text { - Landscape reconstruction of existent objects of green economy }\end{array}$ \\
\hline $\begin{array}{l}\text { 3. Restoration of destructed lands and } \\
\text { fruitful soils }\end{array}$ & $\begin{array}{l}\text { - Conservation of degraded, low-productive and anthropogenically polluted } \\
\text { agricultural lands with their further foresting } \\
\text { - Increase of the percent of recultivated lands } \\
\text { - Use of international experience and new technologies at restoration of destructed } \\
\text { lands and their recultivation }\end{array}$ \\
\hline
\end{tabular}

Financing of ecological projects in Ukraine is possible from different sources. The following international programs function at the territory of Ukraine (Table 2).

Table 2

Existing grants and ecological programs of Ukraine

\begin{tabular}{|c|c|}
\hline International program & Directions of activity \\
\hline $\begin{array}{l}\text { National fund of environment protection and water economy // } \\
\text { NarodowyFunduszOchrony ŚrodowiskaiGospodarkiWodnej } \\
\text { http://www.nfosigw.gov.pl }\end{array}$ & $\begin{array}{l}\text { Balanced development and environment protection } \\
\text { water resources and water economy }\end{array}$ \\
\hline $\begin{array}{l}\text { Province fund of environment protection and water economy in Lublin // } \\
\text { WojewódzkiFunduszOchrony ŚrodowiskaiGospodarkiWodnejwLublinie } \\
\text { http://www.wfos.lublin.pl }\end{array}$ & Balanced development and environment protection \\
\hline $\begin{array}{l}\text { European commission // EuropeanCommission } \\
\mathrm{http}: / / \text { www.cordis.lu }\end{array}$ & $\begin{array}{l}\text { Balanced development and global changes of eco- } \\
\text { system and also grants for travels of scientists and } \\
\text { researchers (SDME) and organization of common } \\
\text { conferences (INCO) }\end{array}$ \\
\hline $\begin{array}{l}\text { Center of world monitoring of biodiversity preservation / } \\
\text { UNEPWorldConservationMonitoringCentre } \\
\text { http://www.unep-wcmc.org }\end{array}$ & $\begin{array}{l}\text { Gives annually } 6 \text { grants for scientists' work in the } \\
\text { Center of Cambridge in questions of preserving } \\
\text { biodiversity and balanced nature management }\end{array}$ \\
\hline $\begin{array}{l}\text { Program for environment protection // BP Conservation Programme, c/o } \\
\text { BirdLife International }\end{array}$ & nvironment protection \\
\hline
\end{tabular}


The use of financing of international nature protection funds in Cherkasy region is limited by the lack of civic ecological organizations' participation in international ecological projects, directed on the natural-reserve affair. Several international programs function in Cherkasy region: international project «Water Harmony Erasmus + »; international grant «Cherkasy Green Energy» project was received at participation of scientists of Cherkasy state technological university. Une fortunately, local scientists and public workers are not involved in grants on international nature protective foundation that support scientists in problems of saving the bio-diverse and balanced management, first of all, because of the language barrier and absence of the experience of cooperation with such organizations.

5. 2. The estimation of prospects of introduction of the program of increasing energy efficiency and energy saving of Cherkasy region with the development of transnational cooperation

Successes of the development of alternative energy sources in the world demonstrate that Ukraine is essentially retrograde in this direction. Solution of energetic problems in Ukraine is a priority of its state policy that is reflected in the Program of energy independence of Ukraine [22]. The country takes into account the experience of the energetic market development in Europe and accents the development of alternative energy sources that will become the most fast growing resource, according to prognoses of international organizations. Their consumption will grow in average by $7,6 \%$ for year and increase in four times in following 20 years due to the growth of the competitiveness level of both solar and wind energetics. The base variant of the prognosis of IRENA (International Renewable Energy Agency) for the period from 2013 to 2030 provides the general growth of energy production volumes in almost 2,5 times (36800 TW·hour) at the expanse of growing production volumes of electric energy of WPP (from $3 \%$ to $7 \%$ ), SPP (all types - from $1 \%$ to $4 \%$ ) and hydroenergetics (from 15 to $16 \%$ ) [23].

Cherkasy region occupies 13th place in Ukraine by industrial production volumes and is an agrarian-industrial region. Its industrial complex combines 12 branches, among which the most importance belongs to food and chemical production. Real electric energy production in Cherkasy region for 2013 was 2,1 bil $\mathrm{kW}$ at consumption - 3,1 bil kW/hour that is the region belongs to energy-deficit ones of Ukraine. The most share of energy production is covered by Kaniv HPP (55,7 \%), the other powerful enterprise is Cherkasy HPP - 40,2 \%. The growth of prices for energy sources needs non-standard solutions for providing energy sufficiency of the region. Under these conditions there is a necessity to realize arrangements in the sphere of raising energy efficiency of Cherkasy region, especially creating necessary conditions for the development of enterprises of housing-municipal economy that use energy effective technologies, demonopolization of the market of energy resources and services, modernization of existent capacities and introduction of innovative technologies using alternative energetics. In 2012-2015 there was elaborated and accepted the Program on raising energy efficiency in Cherkasy region [24], that admitted the following non-traditional and renewing energy sources as priority ones for Cherkasy region:

- Use of solar energy, which summary potential in the region is 24,2 MW-hour/year and technical potential - 11,6 MW·hour/year;

- use of the hydroenergetic potential of small rivers, which summary potential in the region $331,0 \mathrm{mln} \mathrm{kW}^{*}$ hour/year and technical potential - 219,0 MW*hour/year;

- Use of agricultural biomass (the amount of dung in the region is near 13,0 mln t/year, which biogas output is $682,0 \mathrm{mln} \mathrm{m} 3 / \mathrm{year}$, the use of such amount of biogas replaces near 545,0 thousand t.c.f/year of organic fuel), at that the potential of agricultural biomass in the region is 7356,0 thousand MW/year;

- The energetic potential of forest wastes for being used as fuel is 24,8 thousand $\mathrm{m} 3 /$ year in the region, their use allows to save near 4,9 thousand t.c.f./year.

For today Ukraine has a lot of instruments that allow to involve money for realization of energy effective projects. Sources of costs of their realization are also very different. It is most urgent to involve money from external sources that is conditioned by the real absence of own free costs in enterprises and organizations. State and international programs of energy efficiency increase function in Ukraine (Table 3). 
Table 3

International programs of energy efficiency increase in Ukraine

\begin{tabular}{|c|c|c|c|c|}
\hline Support supplier & Program name & Term & Financing & Priorities \\
\hline EU & $\begin{array}{c}\text { Direct support of } \\
\text { Ukrainian budgetary } \\
\text { programs }\end{array}$ & From October 2011 & $\begin{array}{l}31 \mathrm{mln} \text { euro in October } \\
\text { of } 2011.70 \mathrm{mln} \text { euro in } \\
2011-2013\end{array}$ & $\begin{array}{l}\text { Energy-saving technolo- } \\
\text { gies in the state sector }\end{array}$ \\
\hline EBRD & Ukr ESCO & current & $34 \mathrm{mln}$ euro & $\begin{array}{c}\text { Small and middle } \\
\text { companies in industry }\end{array}$ \\
\hline EBRD & Energetic alliance & current & $7 \mathrm{mln}$ euro & $\begin{array}{l}\text { Equipment for } \\
\text { co-generation }\end{array}$ \\
\hline EBRD & UKEEP & current & $105 \mathrm{mln}$ euro & $\begin{array}{l}\text { Small and middle } \\
\text { companies in industry }\end{array}$ \\
\hline UNPD & $\begin{array}{l}\text { Market transformation } \\
\text { for promoting energy } \\
\text { effective lightening }\end{array}$ & $2011-2015$ & $31 \mathrm{mln}$ euro & $\begin{array}{c}\text { State organizations and } \\
\text { houses }\end{array}$ \\
\hline USAID & $\begin{array}{l}\text { Project of heat supply } \\
\text { reformation }\end{array}$ & current & $16 \mathrm{mln}$ euro & $\begin{array}{l}\text { Local heat supplying } \\
\text { companies }\end{array}$ \\
\hline
\end{tabular}

Main programs of international donor organization in today Ukraine include:

- European Union: Partnership of countries of the Eastern Europe for environment protection and energy saving (“E5P”).

- Initiative on energy saving in buildings in countries of the Eastern Europe and The central Asia (ESIB).

- German international cooperation (GIZ).

- NEFCO, Northern ecological financial corporation.

- International financial corporation (IFC): project "Energy efficiency in the housing sector of Ukraine".

- NEFCO: DemoUkraina, energy effective demo-projects in the heat supply sector of Ukraine.

- Suisse Agency of development and cooperation (SDC).

- The program of the Mission of the German Federative Republic in Kyiv.

According to the analytic report of the expert group IB Centre [25], among the total number of objects of renewing energetics, built in Ukraine in the first half-year: solar power plants - 67; total capacities of solar power plants grew by $132 \mathrm{MW}$ or by $23 \%$ in the first half-year relative to the index of 1 of January of 2017 to $705 \mathrm{MW}$. According to the data of the Ukrainian Wind-energetic Associt ation, capacities of wind-parks grew for the report period by 20,7 MW (+4,7\% from the beginning of the year) - to 458,7 MW. At the same time capacities of small HPP and electric generation objects on biomass grew for the first half-year by $2 \mathrm{MW}$ - to $120 \mathrm{MW}$ and to $33 \mathrm{MW}$ respectively. For six months of 2017 investments in RES projects exceeded $210 \mathrm{mln}$ euro. According to data of IBCentre, till the end of 2017 Ukrainian and foreign developers will realize in Ukraine more than 70 new inh vestment projects in the sphere of renewing energetics with the total established capacity more than $430 \mathrm{MW}$. Thus, the results of total capacities of objects of renewing energy in Ukraine in 2017 can reach $1,9 \mathrm{GW}$ that is more than $4,3 \%$ in the total energy balance, says Ecotown [25].

The one of ways of solving the problem of energy deficit in Cherkasy region is introduction of alternative energy sources. Since 2011 there have been activated 3 solar power plants, namely: Gordashivska SPP (capacity 102,5 kW), I turn of photo power plant on the roof of the building at Gromov street 138/6, Cherkasy city (capacity $30 \mathrm{~kW}$ ), SPP "Ozirna" in the city Zvenigorodka (capacity CEC $150 \mathrm{~kW}$ ). II turn of photo power plant on the roof of the building at Gromov street $138 / 6$, Cherkasy city (capacity $30 \mathrm{~kW}$ ) was activated in 2016. It is planned to restore and to put into operation Buh and Voronyanska HPP in 2017.

In 2015 the regional administration accepted the regional program of the development of small hydroenergetics in Cherkasy region till 2020 [26]. For today Cherkasy region is included in the first five Ukrainian regions (Vinnitsia, Zhytomyr, Khmelnitsky and Ternopil) by the number 
of active small HPP. It is planned to reconstruct existent and to build new hydrosystems with small HPP with capacity to $10 \mathrm{MW}$ on rivers of the region. For today the contribution of small HPP in the regional energetics is rather small - near $1 \%$ of total production and more than $22 \mathrm{mln} \mathrm{kW} /$ hour of pure electric energy in a year. Their help is felt in morning and evening hours, when the load on the electric network essentially grows. In total the hydroenergetic potential of the region is $219 \mathrm{mln} \mathrm{kW/hour.} \mathrm{The} \mathrm{use} \mathrm{of} \mathrm{such} \mathrm{capacity} \mathrm{will} \mathrm{favor} \mathrm{the} \mathrm{socio-economic} \mathrm{development} \mathrm{of} \mathrm{the} \mathrm{re-}$ gion and will allow to produce the additional amount of energy. At the same time creation of HPP water bodies is connected with the great influence on the relief, climate, human economic activity in flooding regions. Economic results of water bodies' creation can be estimated by two types of different expenditure. The first one - costs, necessary for compensating caused losses, when they are unavoidable. The other - costs for compensating moneys for preventing or limiting expected negative results of building. There are essential negative ecological results of building new small HPP or reconstructing them, connected with the change of the hydrologic regime of small and middle rivers. The development of small hydroenergetics causes essential threats to the environment, especially for small and middle rivers $[27,28]$ Global climate changes result in essential temperae ture fluctuations and disturbance of the water balance of rivers, which fact needs the additional studying of remote ecological results of building new small HPP, but investors of such products are not interested in it.

According to the data of the association "Ukrhydroenergo", favorable investment conditions give Ukraine a possibility to get additionally near $2000 \mathrm{Mw}$ of established shunting capacity at restored and newly built small hydro power plants. At 2016 near 30 private companies that invest in renewing energetics function in Ukraine. The most of them are: EEA "Novosvit", ltd "Energoinvest" and others. Investments were directed mainly in Vinnitsia, Cherkasy, Khmelnitsky, Ternopil, Zhytomyr regions. For today, 64\% of the total number of stations are placed there, whereas the technical hydropotential of small rivers in these regions in only $14 \%$ of the total one [29].

Since 2001 there have been started works on reconstruction of small hydroenergetics. The main executor on reconstruction of small hydro power plants in Cherkasy region became the Ukrainian energetic consortium, further reorganized in the external economic association "Novosvit" (Vinnitsia city) and its Cherkasy branch (EEA "Novosvit"). During 15 Gordashivska, Zvenigorodska, Korsun-Shevchenkivska, Lotashivska, Lisyanska, Steblivska HPP were reconstructed and returned to operation on small rivers of the region, the new Korsun-Shevchenkivska mini-HPP was built. The total capacity of hydro power plants (together with Kaniv HPP) is $449,7 \mathrm{MW}$, or $58 \%$ of the summary capacity of all electric power plants of the region (774,5 MW). They produce $17,3 \mathrm{mln} \mathrm{kW} /$ hour of energy in a year or $56 \%$ of total regional production that is equivalent to 6 tons of conventional fuel.

The locations of energy-generating capacities of Cherkasy region taking into account small HPP are presented on Fig. 1. Relief differences in the zone, adjacent to small rivers are very little. That is why building hydro power plants of $10 \mathrm{MW}$ capacity is not expedient because of possible flooding of large zones of agricultural lands. So it is economically expedient to create objects of small hydroenergetics with capacity less than $10 \mathrm{MW}$ in the region. The regional program of the small hydroenergetics development in Cherkasy region plans to build mini-HPP with aggregates of siphon type with capacity $100 \mathrm{~kW}$ with capital investments $1 \mathrm{mln}$ hrn on r. Ros in v. Stebliv of Korsun-Shevchenkivsky district. Small HPP in plain conditions are jetty by technical possibilities that results in creation of artificial water bodies and generates a series of ecological problems for territorial communities. Negative ecological results include disturbances of the hydrological regime of middle and small rivers, their eutrophication, worsening of geological conditions.

Studies of the ecological state of r. Ros within Korsun-Shevchenkivska and Steblivska small HPP demonstrated an unsatisfactory picture. Anthropogenic loads essentially changed ecological conditions of habitation of fish in the lower reaches of r. Ros that essentially influenced the structure of fish groups in both qualitative and quantitative aspects. The main cause of it is the regulation of Dnipro's drainage. The expressed regularity, typical for almost all plain rivers is observed for r. Ros - the specific composition of ichtiofauna and its quantitative characteristics change from the mouth to the springhead [30]. 


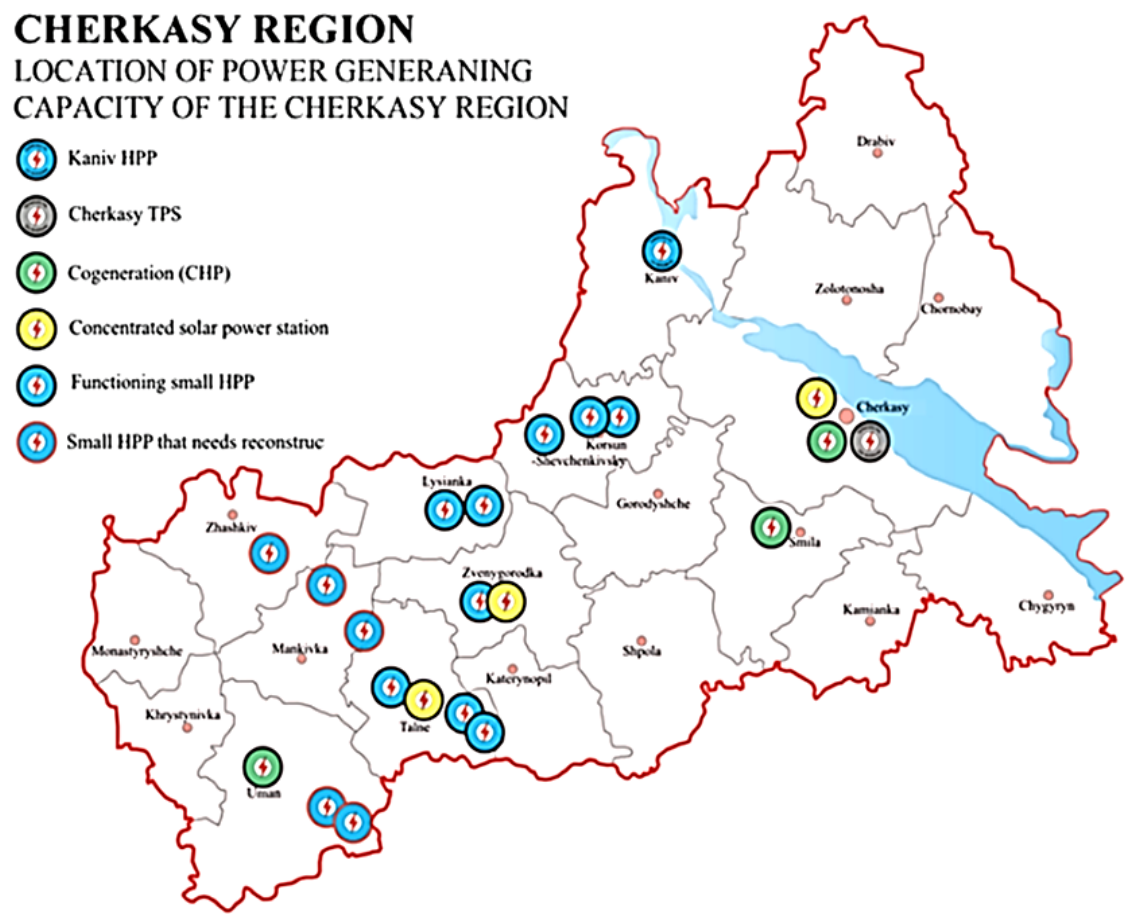

Fig. 1. Map of locations of energy-generating capacities in Cherkasy region

The mean ecological index of the basin is 2,3 , that is its ecosystem is imbalanced. The main load is endured by the water medium (lakes, water bodies). The ecological index of water in the period of winter mean water was high $-1,75$. At other stages of the hydrological regime the water quality was within I class, but at the spring overflow the increase of $\mathrm{BCO}_{5}$ took place, at the summer mean water and in autumn - exceed by phosphates. According to the estimation of water aptitude to economic-everyday needs, the limiting criteria were: the content of organic substances, chrome ions and inessential bacterial pollution.

In total, most small rivers in the Ros basin demonstrate pollution with oil products, nitrogen compounds. Somewhere MPC exceed by coli-index, CCO, some heavy metals (cuprum, zinc, nickel) was observed. The correspondent regime is not observed at territories of water protected zones and riversides. Requirements as to planting agricultures are not fulfilled, as a result organic substances, mineral fertilizers, poisoning chemicals, fertile layer of soil are washed out from fields in the hydrographic network. The agricultural use is in average $71 \%$, and forests only $11 \%$.

Essential volumes of throwing of foul water and washout from urbanized territories, combined with decreasing water amount of rivers, so their ability to self-purification, condition the quality decrease of water of small rivers of the basin. The decrease of water amount of rivers is caused by both changes at the catchment and essential water intakes for agricultural needs.

Today Ros suffers from the ecological trouble. Jetties, water bodies, built along the whole length of it essentially increased the evaporation area. Water intakes (especially the great sluice to Uman) abruptly decreased the speed of the water stream. The use of phosphate powders by the population and absence of proper cleaning facilities led to mass spreading of blue-green water plants in the river. Its level fell by $1 \mathrm{~m}$ in the middle stream. In drying periods the water level decreases to critically low values, turbines of power plants, placed on it, don't work. In the spring period of fish spawning and overflow norms of throwing down water are not observed by private power plants. It results in death of freshwater fish roe and population decrease. This all led to stagnation, oxygen impoverishment of the water in r. Ros. The natural ecosystem is broken. The river lost the ability to self-purification. As a result water of r. Ros, that was transparent to the very bottom, today reminds of broth. Its transparency doesn't exceed 20-30 today [31].

The conducted analysis of water at Steblivska and Korsun-Shevchenkivska HPP demonstrated that the worst water indices by the content of dissolved oxygen, $\mathrm{CCO}$ and nitrates were in 
spring in samples, taken below Korsun-Shevchenkivska HPP, at the place of throwing water after passing through the turbine of HPP. The analysis of reports of the regional management of water resources in Cherkasy region demonstrated the exceed of maximal permissible concentrations by the parameters: $\mathrm{CCO}$ - in 1,3 times at Bilotsetkivsky water intake, in 1,5 times at Boguslavsky water intake and in 2,3 times at Korsun-Shevchenkivsky water intake, that is the quality worsening was observed in the low stream of $r$. Ros.

The decrease of NSL of r. Ros in the low stream, where Steblivska and Korsun-Shevchenkivska HPP are located, testifies that these facilities function under conditions of the insufficient normal support level of water that favors ecological problems, connected with shallowing of small rivers that fall in r. Ros. Under these conditions ecological risks of building mini-HPP on r. Ros in v. Stebliv exceed economic expedience and need correcting the regional program of the development of small hydroenergetics in Cherkasy region. Under conditions of global warming, the amount of precipitation in Cherkasy region changes that results in decreasing the water-pressure level at existent small HPP and decreasing their productivity. Under new conditions the external economic association "Novosvit" decided to use solar and water energy in combination, and fixed solar power stations with capacity $102,6 \mathrm{MW}$ on jetties of Gordashivska and Zvenigorodska small hydro power plants. It is planned to build a ground solar power plant with capacity $25 \mathrm{MW}$ near c. Kamyanka of Cherkasy region.

From the ecological point of view, the essential regulation of middle and small rivers of Cherkasy region, decrease of precipitation amount and disturbance of the hydrological regime of rivers as a result of restoring and building new small HPP is unreasonable comparing with solving energetic problems of the region and results in the excessive anthropogenic load and ecological tension in the region.

Cherkasy region produce alternative fuels together with restoring small HPP, namely: LTD "Harvest" in 2016 produced $237 \mathrm{t}$ pellets of straw; IE "Transbiofuel” produced $982 \mathrm{t}$ of granulated biofuel of wood wastes; LTD “Aver-tech" produced $2130 \mathrm{t}$ pellets; IE Lebyd V.P. produced $40 \mathrm{t}$ of hard biofuel of corn peeling; LTD "Khristinivka-food goods" produced $907 \mathrm{t}$ of briquettes; ISC "Chernobay plant of food goods" produced 11t of pellets of sunflower peeling; PPE Tkachenko S. A. produced $72 \mathrm{t}$ of briquettes of sawdust; PPE Gorbach O. G. produced $135 \mathrm{t}$ of pellets; IE Marchenko G. V. produced $25 \mathrm{t}$ of pellets of sunflower peeling. The development of this segment of alternative energy sources gives essentially more perspectives for local communities than renewal of small HPP in the region.

The essential help to local communities in solving problems of energy efficiency is given by the international project "Local development, oriented on the community". It has functioned in Ukraine since 2008. All initiatives are successfully realized due to combined efforts of local dwellf ers, local, district and regional authorities, sponsors and initiators of the project itself - European donors. The contribution of communities in the project is only $5 \%$. The first phase of the project that took place from 2008 to 2011 covers 8 districts of Cherkasy region, where 54 micro-projects were realized. The second phase that lasted from 2011 to 2014, involved 13 districts, where 69 micro-projects were realized. And now there is the third phase, started from 2014, and must last till 2018. Millions hryvnias were spent within each phase. At the beginning of the project the village community must create the non-profitable public organization then define most important problems that need solutions. Most applications were devoted to energy saving in educational institutions, ones of health protection, street lightening and repair of water pipes in local communities.

\section{3. The analysis of perspectives of the green tourism development in the context of sustainable development of Ukraine on the example of Cherkasy region}

Today tourist industry undergoes the active development and formation of new directions. In parallel with traditional types of tourism, some non-traditional types of rest and travels spread. The tourism sphere is more and more influenced by spreading ideas of life ecologization. Most European countries attract to village tourism at the state level. It's not an occasion that the share of eco-travels in these countries is more than $20 \%$ of all tourist services, and rates of the annual increment reach $30 \%$. [32]. Village tourism organization faces new tendencies, connected with the globalization process. Globalization in the tourist sphere, first of all, provides elimination of any barriers in international tourist exchanges, tourist "decrease" of the globe due to cheapening transcontinental flies 
and creation of the infrastructure more or less even by the service level in all world countries without exclusions and so on. Globalization in village tourism and agrotourism gains momentum, first of all, by introducing global data banks of agrotourist supply of the planet and mechanisms of global e-trade of these services [33]. Especially, the most effective global information system of booking village tourism and agrotourism in all world regions is presented in Table 4 [34]. This e-system, according to its reports, already provides practically $7 \%$ of world sales of agrotourist services. And in the nearest perspective the role of such information systems must became determining in the system of global promotion and sale of village tourism services in the world.

\section{Table 4}

Official web-sites of national organizations of village tourism and agrotourism in European countries and most tourist countries of the world

\begin{tabular}{|c|c|}
\hline Country & Official web-site of national organizations of village tourism and agrotourism \\
\hline Austria & $\begin{array}{l}\text { http://www.farmholidays.com } \\
\text { http://www.agritours.com }\end{array}$ \\
\hline Australia & $\begin{array}{l}\text { http://www.caloundraaccommodation.com } \\
\text { www.farmstayholidays.com.au }\end{array}$ \\
\hline Belgium & http://www. gitesdewallonie.net \\
\hline Bulgaria & www.alternative-tourism.org \\
\hline Brazil & $\begin{array}{c}\text { http://www.abtr.com.br } \\
\text { www.visitbritain.com }\end{array}$ \\
\hline United Kingdom & $\begin{array}{c}\text { www.farmstayuk.co.uk } \\
\text { www.bedandbreakfastnationwide.com }\end{array}$ \\
\hline Greece & www.guestinn.com \\
\hline Denmark & www.bondegaardsferie.dk \\
\hline Ireland & http://www.country-holidays.ie \\
\hline Iceland & www.farmholidays.is \\
\hline Spain & $\begin{array}{l}\text { http://www.raar.es } \\
\text { www.ecoturismovillage.com }\end{array}$ \\
\hline Italy & http://www.agriturist.it \\
\hline Cyprus & www.agrotourism.com.cy \\
\hline Latvia & $\begin{array}{c}\text { http://www.celotajs.lv } \\
\text { www.traveller.lv }\end{array}$ \\
\hline Litvania & $\begin{array}{c}\text { http://www.lithuaniancountryside.com } \\
\text { www.atostogos.lt }\end{array}$ \\
\hline Luxembourg & $\begin{array}{c}\text { http://www.ont.lu } \\
\text { www.gites.lu }\end{array}$ \\
\hline Mexico & http://www.guestranch.com \\
\hline Netherlands & http://www.dutch-farmholidays.com \\
\hline New Zealand & http://www.villagetours.co.nz \\
\hline Norway & $\begin{array}{l}\text { www.bbnorway.com } \\
\text { www.norsk-bygdeturisme.no }\end{array}$ \\
\hline Poland & www.agritourism.pl \\
\hline Romania & http://www.antrec.ro \\
\hline Serbia & www.cenort.org.yu \\
\hline Slovakia & www.agroturist.sk \\
\hline Slovenia & www.slovenia-tourism.si/?podezelje_l $=0$ \\
\hline USA, Canada & $\begin{array}{l}\text { http://www.duderanchvacations.com } \\
\text { http://www.vacationranches.com }\end{array}$ \\
\hline Finland & www.lomarengas.fi \\
\hline France & $\begin{array}{l}\text { http://www.gites-de-france-47.com } \\
\text { www.gites-de-france.com }\end{array}$ \\
\hline Czechia & $\begin{array}{l}\text { www.accommodation.cz } \\
\text { www.eceat.cz }\end{array}$ \\
\hline Croatia & www.istra.hr \\
\hline Switzerland & www.bauernhof-ferien.ch \\
\hline Sweden & http://www.bopalantgard.org \\
\hline
\end{tabular}

Source: European experience of village green tourism organization. Tourist Library(2017), http://infotour.in.ua/siltur2.htm 
All national organizations of village tourism, and agrotourism of European countries at the end on 1990-s combined in the European Federation for Farm and Village Tourism. The short form of its name - «Euro Gites». Today Euro Gites considers a question as to admission of the Ukrainian union of favoring the development of village green tourism as a full-fledged member.

Village tourism persuasively proved that it is an important factor of solving socio-economic problems of villages - the growth of employment at villages, development of the village infrastructure, getting sustainable and essential profits of rural dwellers, strengthening of budgets of rural settlements. Ukraine is exceptionally rich in diverse monuments of nature, history and culture, national traditions, possibilities to get eco-friendly products, rest on beautiful nature. The international image of village rest in Ukraine is ambiguous. On the one side, Ukraine is traditionally understood as an agrarian country, as one of European granaries with the preserved village life style, rich cultural heritage, with saved nature and hospitable masters. From the other side, foreign tourists are not attracted by the relatively low dwelling standards and insufficient technical equipment, and also uncomfortable villages and rather limited choice of leisure and possibilities of active rest. But the last year tendencies testify that Western countries find a perspective of Ukrainian village rest and tourism at the international tourist market. It is demonstrated by the organizational and technical help of international Funds, for example, the Fund of Carpathian euroregion development, TAGS program, due to which, projects of supporting village rest and tourism in Ukraine were realized [34].

The analysis of the green tourism development in Ukraine demonstrates that village green tourism is most developed in Carpathians in Ukraine [32]. It is mainly conditioned by natural conditions, developed sanatorium-resort infrastructure with sources of mineral waters, famous mountain ski resorts such as Slavske and Bukovel that attracts fans of winter rest. The positive role in establishing village (green) tourism just in Carpathian region was played by the traditionally high level of unemployment that forced the population to solve problems of own employment independently by the development of this tourist sector, using the favorable conjuncture of last years. Village (green) tourism in Crimea was developed much less than Carpathian. It is connected with the fact that the main tourist flow is directed on summer rest in resort zones at seaside itself, where the most mass rest is in the Crimea private sector. Winter rest in Crimea gradually reaches popularity at improving the tourist infrastructure. Village tourism gains more popularity that is testified by appearance and activation of such organizations as Crimean association of village green tourism. Green tourism is least developed in the Eastern Ukraine. Such densely dwelled regions as Lugansk and Donetsk have only one tourist farmstead in each of them, whereas the real demand for rural rest in these highly urbanized districts is rather high and only partially satisfied by the supply of rest at the seaside or in other regions. The analysis of the green tourism development in Ukraine, realized in 2013 by Darchuk V.G. demonstrated that most number of registered farmsteads is in the followe ing regions: Trancarpathian (21), Kyiv (12), Khmelnitsky (8) Chernihiv (8), Cherkasy (7). Totally near 91 village green farmsteads were counted in Ukraine in 2013, that is very low index compars ing with other European countries taking into account the number of villages, village dwellers and high potential in the development of village (green) tourism in Ukraine. Last years, green tourism undergoes the real boom in Ukraine, especially in the central regions. According to the data of Cherkasy state administration, in 2017 already 40 green farmsteads were counted, so their number increased almost 6 times during 4 years of observations. Most popular "green" zones are located in Chigirin and Cherkasy regions - nearest to the regional center. The fast development of green tourism in Ukraine may be explained by using international tourist sites for attracting tourists. In this sense green tourism can be an example of successful transnational cooperation of the central regions of Ukraine with world countries. The motivation of its development is also the improvement of farmstead masters' welfare that results in growing supply from local village communities.

\section{Conclusions}

1. Regional eco-networks are the component of formation of the national and international eco-network in Europe. The main reserve for forming regional eco-networks is water fund lands, degraded and low-productive landscapes. The main threat to building the national eco-network is 
unessential financing and absence of interest in increasing areas of the natural-reserve fund among local communities. Non-coordination in determining ownership right for lands, limitation of possibility for using natural resources at alienating lands in the natural-reserve fund causes resistance of local authorities and negative attitude among the local population.

2. Solution of problems in realization of regional eco-networks is possible by conducting the educative work among the population, conserving degraded, low-productive and anthropogenically polluted agricultural lands with their further foresting and elaboration of offers for owners, which rights for lands use are limited, by local authorities.

3. Involvement of financing from international donor organizations by local authorities for solving the problem of energy saving is used not completely and is realized by setting individual contacts.

4. The lack of experience in getting international grants for improving energy saving may be solved by conducting trainings for representatives of local authorities and help by the regional authorities in creating the active dialog between representatives of European and Ukrainian communities with exchanging experience in solving such questions.

5. The fast growth of the percent of alternative energy sources in the structure of the energetic branch takes place in Ukraine. The development of small hydronergetics for the central regions is not very promising, because as a result of climatic changes, the very existence of small and middle rivers is threatened. The best solution of the energy deficit of regions is a combination of alternative energy sources. The central regions of Ukraine are agro-industrial, so it is also promising to get fuel from green mass. It is necessary to involve local authorities in information about existent technologies and experience of using green fuel in the World actively, to help in searching investors and realization of programs of introducing "green" technologies in heating at the local level.

6. The fast development of green tourism in Ukraine testifies that it is most promising in international cooperation for the central regions of Ukraine.

\section{References}

[1] Sukhyi, T. A., Zhytariuk, V. V. (2012). Development of cross-board cooperation of Ukraine. Available at: http://nauka.kushnir.mk.ua/?p=8946

[2] International Technical Assistance and Regional Development (2016). Available at: http://dialog. lviv.ua/en/mizhnarodna-tehnichna-dopomoga-ta-regionalniy-rozvitok-2/

[3] A. Jakubowski, A. Miszczuk, B. Kawako (2016). The EU's New Borderland: Cross-border Ref lations and Regional Development, 202.

[4] On the intensification of cooperation between Ukraine and the European Union within the framework of the Euroregions and prospects of cross-border cooperation (2007). Verkhovna Rada of Ukraine. Available at: http:/www.zakon.rada.gov.ua

[5] Antonyuk, U. W. Legal protection of the environment in Poland (2016). Scientific Herald of Kherson State University. Section of Legal Sciences, 2 (2), 7-10.

[6] Romanko, S. M. (2013). Environmental Policy of Ukraine and Poland: Aspects of Relationship. Available at: http://www.polukr.net/blog/2016/05/biuletyn-polsko-ukrainski-polityka-prawo-wspolczesnejeuropy/

[7] Kravtsev, V. S. (2016). Development of cross-border cooperation. U.S. Institute for Regional Studies of the National Academy of Sciences of Ukraine. Problems of Regional development, 125.

[8] Lukanyuk, W. Carpathian Convention as an way for ensuring the ecological well-being of the local population (2012). Actual problems public administration, 3 (51), 81-85.

[9] Project «Support for Nature Reserve Areas in Ukraine» (2016). Available at: http://wwf.panda. org/uk/our_work/forests/pas/pas_support_in_ukraine/

[10] Millennium Development Goals (Ukraine: 2010) National Report (2011). Available at: https://unaids.org.ua/ua/korisna-informatsiya/zviti-analitika-dovidniki/tsili-rozvytku-tysiacholittia-ukraina-2010-natsionalna-dopovil

[11] Bennett, G., Wit, P. (2001). The Development and Application of Ecological Networks: a Review of Proposals, Plans and Programmes. Available at: https://portals.iucn.org/library/sites/library/files/ documents/2001-042.pdf 
[12] Bennett, G., Mulongoy, K. J. (2006). Review of Experience With Ecological Networks, Corridors and Buffer Zones. CBD Technical Series, 23. Montreal: Secretariat of the Convention on Biological Diversity, 98. Available at: https://www.cbd.int/doc/publications/cbd-ts-23.pdf

[13] Natura networking programme 2000. Available at: http:/www.natura.org

[14] Convention on the Conservation of European Wildlife and Natural Habitats: International Document (1979). Available at: https://www.ecolex.org/details/treaty/convention-on-the-conservation-of-european-wildlife-and-natural-habitats-tre-000473/

[15] Deynega, M. A. (2013). European Ecological Network: Legal Principles of Formation (2015). Scientific Bulletin of the National University of Bioresources and Natural Resources of Ukraine, 1, 77.

[16] Samolylenko, W., Kogoroda, N. (2013). Regional and local ecological networks. 192.

[17] Odum, Eu. (1986). Ecology. Moscow: Mir, 328.

[18] State strategy of regional development of Cherkasy region for the period till 2020 (2015). Available at: http://www.csi.org.ua/www/wp-content/uploads/2013/05/nsrdu2020_1.pdf

[19] Gayova, J. (2010). National park «Cherkassy Bir» - a center for the conservation of biodiversity in the Middle Dnieper. Balanced (sustainable) development of Ukraine - the priority of national policy. AllUkrainian scientific ecological conference. Kyiv, 168-171.

[20] On the Program of Prospective Development of the Reserve Case in Ukraine (1994). No. 177/94BP. Verkhovna Rada of Ukraine. Available at: http://zakon5.rada.gov.ua/laws/show/177/94-\%D0\%B2\%D1\%80

[21] On the National Program for the Formation of the Ecological Network of Ukraine for 2000-2015 (2004). Verkhovna Rada of Ukraine, No. 1864-IV. Available at: http://zakon2.rada.gov.ua/laws/show/177/94$\% \mathrm{D} 0 \% \mathrm{~B} 2 \% \mathrm{D} 1 \% 80$

[22] The program of energy independence and energy reform (2017). Available at: http://reformsguide.org.ua/analytics/energyreform-2/

[23] The main provisions of the energy strategies and programs of the European Union on the development of the energy sector in the context of the creation of a pan-European electricity market (2017). Kyiv, 92. Available at: https://ua.energy/wp-content/uploads/2017/05/2.-Energetychni-Strategiyi-YES.pdf

[24] Program on increasing energy efficiency and reducing energy consumption of Cherkasy region for 2011-2015 years (2016). Available at: www.rayrada.ck.ua/document/rishennia-sesii/6/11/1.doc

[25] Innovative Business Centre: Annual Report for Ukraine (2017). Available at: http:/www.ecoA town.com.ua

[26] Regional program of development of small hydropower in Cherkasy region for 2011-2020 (2011). Available at: http://ua.convdocs.org/docs/index-240493.html

[27] Small scale hydro power: impacts on nature and people (2012). https://www.iucn.org/content/ small-scale-hydro-power-impacts-nature-and-people

[28] Pacesila, M., Burcea, S. G., Colesca, S. E. (2016). Analysis of renewable energies in European Union. Renewable and Sunstainable Energy Reviews, 1, 156-170.

[29] Karamoschka, O. (2005) On the Concept of the State Socio-Economic Program for the Developf ment of Small Hydropower of Ukraine. Power engineering and electrification, 7, 36-41

[30] Zagoruyko, N., Portyanko, K. (2015). Risk assessment of the construction of a new mini hydropower on the Ros River in the Cherkasy region. Problems of Environmental Safety. Kremenchuk, 71-72.

[31] Yatsyk, A., Hopchak, I. V., Basiuk, T. O. (2013). Environmental assessment of surface water quality of the Ros River. Agricultural Sciences, 2 (62), 79-86.

[32] Sokolenko, S., Businsky, M. (2017). Features of activities and development of green tourism objects in the regions and the problems of creating international clusters in this area. Available at: http://tourlib. net/statti_ukr/sokolenko.htm

[33] European experience of rural green tourism organization (2017). Tourist Library. Available at: http://infotour.in.ua/siltur2.htm

[34] Kobernitschenko, T., Wasilyev, W., Gorischewsky, P., Zinko, Eu. (2005). Rural green tourism. Methodical recommendations for owners of farmsteads. Agrarian education, 80. 